\title{
Testing sustainable value added as an integrative measure of business sustainability*
}

\author{
Dejan Miljenovic ${ }^{1}$
}

\begin{abstract}
New analytical approaches used for a holistic/integral evaluation of the company created value advocate implementation of business models based on Corporate Social Responsibility (CSR) sand the Triple Bottom Line (TBL). Owing to the fact that CSR and TBL are strategically oriented on business objectives of sustainable development, especially in managing eco-efficiency, this type of value is being named - Sustainable Value Added (SVA). However, since previous research and constructive criticism of SVA models have not been adequately tested by applying the appropriate econometric models so far, in this paper author introduces applicable empirical testing of the SVA sensitivity on the Triple Bottom Line aspects: 1) financial, 2) environmental and 3) social business results. The aim of this paper is to conduct research on SVA as an integrative measure for quantitative assessment of company contributions to the long-term sustainable development. The author also advocates an important thesis regarding the extraction of the TBL data, implicating that this process validates only when a relevant number of companies, across different benchmarks, regularly publishes annual CSR reports. Such publishing ensures transparent and unified TBL data essential for SVA analysis. Research methodology rests on the comparison of SVA with a traditional economic measure of Value Added (VA) in terms of their contributions to business sustainability. Empirical testing indicates significant differences between the SVA and VA regarding their financial, environmental and social sustainability effects. Testing empirically confirms SVA as an integrative measure for sustainable business contributions. This ensures the presentation of complete and standardized data of triple results required for SVA analysis. Additional objective in this context was to investigate eco-efficiency of a specific benchmark as a sustainability precondition, measured by using the SVA.
\end{abstract}

Key words: corporate social responsibility, sustainable value added, triple bottom line, reporting, company, sustainability

JEL classification: 031, Q32, Q57

\footnotetext{
* Received: 02-05-2017; accepted: 26-03-2018

1 Postdoctoral researcher, University of Rijeka, Faculty of Economics, Ivana Filipovića 4, 51000 Rijeka, Croatia. Scientific affiliation: entrepreneurial economics. Phone: +385 51355 136. E-mail: dejan.miljenovic@efri.hr. Personal website: https://www.efri.uniri.hr/hr/dejan_ miljenovic/195/72.
} 


\section{Introduction}

In the business context, a paradigm of sustainable development has been elaborated within different Corporate Social Responsibility (CSR) theories. There are various and derived CSR definitions where this concept generally represents a set of business policies, strategies and operational guidelines used by companies to manage effects of their operations in a sustainable manner. These are not exclusively financial effects, because CSR approach simultaneously values financial, environmental and social aspects of doing business. When it comes to sustainable development, these three types of aspects in business represent a company Triple Bottom Line (TBL), i.e. an integrative expression for different types of company business results. Moreover, the mainstream CSR theories, such as the stakeholder theory, the legitimacy theory and the institutional theory support this integration. The most appropriate CSR theory in terms of advising contemporary research and in terms of the business TBL, is the institutional theory. Campbell (2007: 946) argues that institutional theory in terms of CSR explains the relationship between basic economic conditions and corporate behavior. This relationship mediates several institutional conditions: public and private regulation, the presence of nongovernmental and independent organizations monitoring corporate behavior, institutionalized norms of appropriate corporate behavior, associative behavior among corporations themselves and organized dialogues among corporations and their stakeholders. Brammer, Jackson and Matten (2012) consider institutional theory crucial for understanding CSR as a mode of governance. According to them "the institutionalization of CSR can be seen in the diffusion of CSR departments within companies, the spread of stock market indices related to sustainability, the proliferation of branding initiatives and even an ISO standard on CSR." (Brammer, Jackson and Matten, 2012: 10). This is also the case with standardized CSR reporting profiled by the government and international organizations (institutions) or stakeholder alliances that promote sustainable corporate to society relationships. Their interest rests on evaluations of non-financial business aspects, primarily environmental and social ones. Non-financial business aspects came to a management focus by their growing participation role in the process of value creation. For example, non-financial business aspects (i.e. environmental and social ones) in 2009 participated in total company value creation at a level of $81 \%$ compared to the financial aspects participating at a level of $19 \%$. In 1975 this ratio was in flavor to financial aspects with $83 \%$ of their participation in the value creation process. However, financial share reduced during the years to $68 \%$ in 1985 and $32 \%$ in 1995 when non-financial aspects gained the lead with a share of 68 \% (International Integrated Reporting Committee - IIRC, 2012: 4). Companies have tried to report this new model of value creation transparently by integrating environmental and social aspects along with the financial ones. In this situation CSR reporting process gained momentum and became promoted institutionalized standards and guidelines. Internationally conducted guidelines, often leveled 
to national reporting practices, include UN Global Compact, Global Reporting Initiative, Stakeholder Alliance, AccountAbility organization and International Integrated Reporting Committee. What lead to creation and implementation of the mentioned initiatives and standards was multi-stakeholder and institutional cooperation. Among 250 largest companies in the 2015, even $63 \%$ of them carried out independent verifications (i.e. audits) of their integrated CSR reporting processes (KPMG, 2015: 40). Verification of CSR reports has two important goals:

\section{1. to improve the transparency of environmental and social information and}

2. to use exact environmental and social information in SVA analysis.

In this paper institutional standardization of CSR reporting is advocated as a source of measuring Sustainable Value Added (SVA). The reason for this is that only standardized data can provide benchmark and cross-country analysis of the companies and their TBL effects on sustainable development. The issue regarding different definitions of sustainable development is not the matter of argument in this paper because these definitions actively adapt according to environment conditions, stakeholder's interests and relevant political, cultural and social issues. Therefore, the meaning of sustainable development always reflects general terms of sustainability applied in economics, engineering, national policies and even cultural orientations.

In addition, this research advocates institutional theory of CSR, theoretically and empirically, by using a model based on TBL data collected from international and national reporting standards. For correct application of the SVA analysis, the company has an obligation to use standardized benchmark data. This type of data generates only when CSR reporting rests on institutional standards and reporting initiatives, guidelines or even national laws. The aim of this research is to integrate CSR and TBL data across those countries and industry sectors where CSR reporting standards already exist institutionally. Only institutional frame ensures enclosed and reliable set of TBL information i.e. including full financial, environmental and social business data. This is a matter of the triple business data integration under one type of report - the CSR report - along with the value it represents, the Sustainable Value Added. However, quantitative measurement of business sustainability aspects within the company TBL is rarely being discussed and statistically analyzed. Elkington (1997: 2) who intertwined CSR reporting as a source of TBL quantitative determination first argued this. Elkington united different sustainable development frameworks of eco-efficiency, ecological footprint, industrial ecology and social equity. In the beginning, there was still significant occupation with justifiability of the CSR business movement. Other authors have taken serious steps forward and conducted research results that recognize specific value added generated in relations of business sustainable development. Esty and Winston (2006) argued that green business strategies represent a way of how smart companies use environmental 
strategy to innovate, create value and build competitive advantage. Value creation based on sustainable business practices started a new initiative - quantification and measurement of business sustainability. Quantification and measurement of business sustainability aspects came to a focus along with the growing environmental and social concerns of global sustainable development. Environmental and social risks provoked by companies became relevant factors of global business sustainability. Mentioned issues left unanswered research question: How to measure and value "non-financial" business results, especially when some of the environmental and social aspects of business operations cannot be quantified? To measure the aspects of business sustainability a number of different indicators are being contemporary developed. These indicators represent quantitative expression of the TBL data. Development of business sustainability measures has a purpose of analyzing company performance (success) by using qualitative aspects of business, especially in the area of ecology, health, safety and social development. In their paper from 2001, researchers Vesela Veleva and Michael Ellenbecker from the Lowell's Center for Sustainable Production support two basic ideas related to development of business sustainability measures (2001: 520$)$ :

1. it is possible to have a standard set of indicators (i.e., indicators applicable to any company); and

2. as Vollmann (1996) points out, it is better to measure the right things approximately than the wrong ones with great accuracy and precision.

However, when it comes to defining the aforementioned measures (indicators) some objective obstacles repeatedly stand out. Determination of the form, and then measuring and presenting indicators of business sustainability, requires constant data tracking due to their qualitative expression. This is utmost important when it comes to decision-making, especially within the companies, where quantification of sustainability indicators is required (Olsthoorn et al., 2001: 457). Quantification also encourages development of sustainability indicators and measures based on monetary analysis. For example, in terms of ecological damages and cost of biodiversity rehabilitation the analysis of negative environmental effects of business usually takes place. However, CSR management strategies are oriented on prevention of such negative effects and proactive evaluation of positive contributions in terms of sustainable development. However, a significant difference in the content of the CSR reports is what often prevented proactive sustainability evaluation. This is again issue of CSR reports standardization. Even standard formats of CSR reports (Miljenović, 2016: 42-48) are not always mandatory and their contents more often subjects to company self-initiative types of social reporting. In addition, there are pronounced sector differences that cause difficulties in comparing sustainability indicators. Reason for this is efficiency of the specific business process that measures differently across different industries. This efficiency cannot be the same in the energy service sector or the food sector 
(Lyrstedt, 2005). Organizational structure also derives across different sectors as a significant factor of business efficiency (Petrini and Pozzebon (2009: 185-187). Taking the above mentioned into account author introduces the hypothesis that SVA can be used as an integrated measure of achieving company efficiency within $T B L$ aspects of financial, environmental and social responsibility. By stating this, the author also implies another crucial element of the research: Testing of the SVA has to be exclusively conducted by using standardized CSR reports that ensure TBL data integrated in a manner to accurately reflect contents of sustainable value. For this purpose, the paper will provide an outlook of the SVA model, relevant literature and related methodology reviews. The scientific research objective is to provide empirical data based on the CSR-TBL theory and SVA methodology used to conduct empirical testing of SVA as an integrative measure of business sustainability.

Further organization of the paper follows into the second section that provides a literature review of basic and contemporary findings. This is where the SVA integrative character is being set in relation to sustainable business performance. In this part, special attention relates to the integration of efficiency parameters within the TBL business model. The third section delivers SVA methodology description with all relevant parameters used in empirical analysis, based on the original SVA model. Additionally, this section provides relevant characteristics for the defined groups of sustainability variables (dependent and independent). The fourth section contains described specifications of the research model and conducted empirical analysis, which is stating all findings relevant for the set hypothesis. The fifth section describes results and accompanying discussion related to economic significance of the empirical testing. Conclusion, as the last section, focuses on results, implications and future research.

\section{Literature review}

Relevant CSR literature successfully balances the issues of CSR theoretical and practical frameworks. Initial critics on CSR that were given by Friedman (1970) stated that a company cannot takeover different types of responsibility because it is not a living being and that a company's only "responsibility" is to maximize shareholders returns (not the contributions to the stakeholders!). According to this company does not have any responsibility to the rest of the society, except the shareholders. However, according to Tideman, (2005: 24), Stanislav Menshikov argues that most people are not "maximizers" but they are "satisfiers"; "they want to meet their needs and be in balance with themselves, with other people, with society and with nature". Decades earlier, this thinking established strong stakeholder theory that was significantly advocated by Freeman (1984). In his work Freeman develops the stakeholders' approach as a strategic management response to internal 
and external changes of the organization and its environment. Significant change in stakeholder relations also refers to the already mentioned process of value creation. Stakeholder approach implies that value is being generated by joint activities of individual stakeholders who interact with a company and other stakeholders through innovation, production processes and exchange processes (Bridoux, Stoelhorst, 2016: 231). Frederick and Post (1992) explained basic stakeholder relations much earlier, in 1976, as a set of relations between business and social groups. This included corporate strategy, public policy and ethics between internal and external company stakeholders. Internal stakeholders are groups that have internal interests in relation to the company, including owners, workers, management, business partners and suppliers. On the other hand, external stakeholders represent investors, media, local community, government, non-governmental groups and activist groups, and public in general. This is a basic theoretical CSR paradigm based on qualitative evaluation of company-to-stakeholder relationship already discussed within mentioned scientific research. However, quantification problem of business sustainability aspects advocated by aforementioned CSR theories was not the regular issue of scientific research, mostly because of its complicity. Therefore, structure and content of this paper and accompanying research has to reflect a significant upgrade of the CSR paradigm, which was, until the SVA measurement, based only on theoretical and qualitative aspects of sustainability. Given references relate only to those business sustainability frameworks and researches dealing with quantitative measurement of company TBL contributions. TBL contributions as a logical outcome of CSR policy application are therefore very clearly stated.

When it comes to the SVA, most relevant findings where provided by a BritishGerman scientific "duo" Frank Figge ${ }^{2}$ and Tobias Hahn ${ }^{3}$. Their research represents chronological development of the sustainable value added concept (Figge, Hahn, 2002, 2004a, 2004b, 2005, 2006 and 2009). Question of the SVA occupied the attention of academic and business community by stating (Figge, Hahn, 2002: 1): "How sustainable is your company? More and more companies have been confronted with this question over the last decade. To answer this question the contributions of companies to sustainability must be assessed." What was the most important, this statement implied the regular absence of a single quantitative measure intended to evaluate different aspects of sustainability in business practice. The approach of Figge and Hahn strongly rests on institutional CSR theory because it presents SVA efficiency and effectiveness elements obtained by implementing institutional CSR reporting regulations. These regulations and standards became crucial source for publishing transparent CSR data. Institutionalized CSR norms

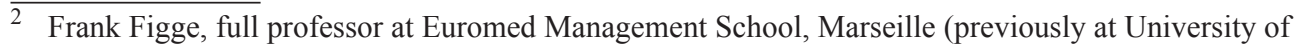
St. Andrews \& Sustainable Development Research Centre, SDRC)

3 Tobias Hahn, associate professor at Euromed Management School, Marseille (previously at IZTInstitute for Futures Studies and Technology Assessment) 
provided dialogue among corporations and their stakeholders with a stronger presence of nongovernmental and other independent organizations that monitor corporate behavior and promote CSR reporting. These are institutional conditions set by Campbell (2007) when discussing responsible corporate behavior. Research conducted by Figge and Hahn (2004a: 174 and 2006) respected institutional framework and started evaluating sustainability from a company level of sustainability (SVA in a single impact case) and sustainability at a macroeconomic level (SVA in a multiple impact case). However, in this paper, these two levels are connected within a cross-section analysis of a specific benchmark (food and beverage industry).

In the original model, SVA insists on company achieving ecological and social efficiency and effectiveness. TBL concept suitably includes both the efficiency and effectiveness for company financial, environmental and social impacts. The whole CSR paradigm insists on simultaneous company efficiency when achieving environmental impacts (eco-efficiency) and social impacts (socio-efficiency). Using the business model that integrates efficiency parameters (represented in Figure 1) enables precise identification of the sources for the long-term business sustainability. These parameters represent non-financial aspects regularly provided by the companies in their CSR reports, respecting full data transparency.

Figure 1: Integration of efficiency parameters within the TBL model

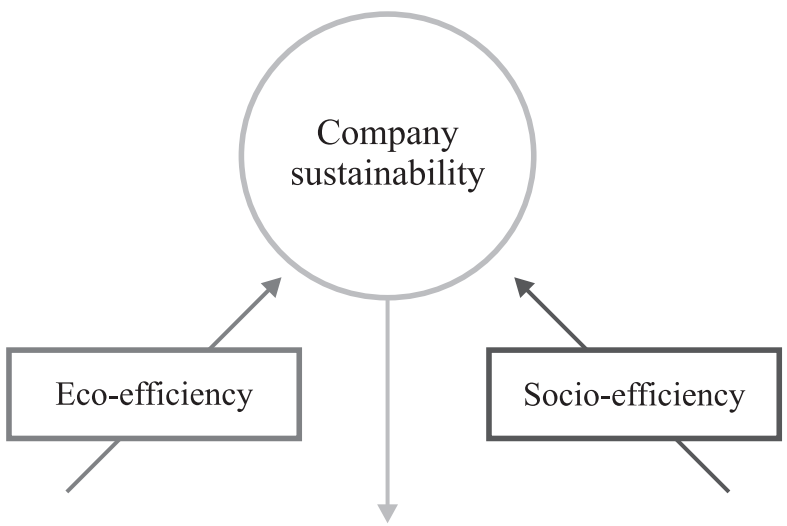

ENVIRONMENTAL SUSTAINABILITY

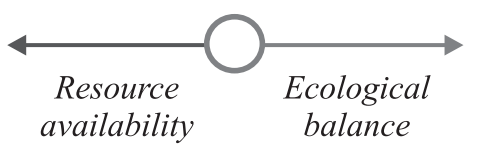

SOCIAL SUSTAINABILITY

Source: Author's adaptation according to Dyllick, T., Hockerts, K. (2002) "Beyond the Business Case for Corporate Sustainability", Business Strategy and the Environment, Vol. 11, No. 2, pp. 130-141. 
Business efficiency relates to numerous possibilities and concepts of achieving balanced results within the TBL. Producing larger quantities of goods and services with a smaller use of available natural resources, materials, water, energy, generated waste and greenhouse gas emissions (GHG) shapes the efficiency of the production process. In production and distribution processes by which company generate financial results it also inevitably affects environment and society in the same time these processes occur. This happens every time when a company uses natural or human resources, as well as accounting all potential effects that may arise from unwinding organizational activities. Therefore, achieving company sustainability depends on indirect and constant levels of eco-efficiency and socio-efficiency. This is a state of mutual interaction between three TBL elements: 1) financial sustainability, 2) environmental sustainability and 3) social sustainability (as shown by Figure 1). For example, a precondition for social sustainability is sufficient allocation of resources required for the upcoming (or future) development. At the same time, only understanding of sustainable development policies and implementation of sustainable business activities can ensure crucial balance between current and future use of available natural resources. To achieve sufficiency of environmental and social resources it is of the utmost importance to engage factors of sustainability within the companies, in which case TBL effects have significant impact (International Integrated Reporting Council, 2012: 4 and International Integrated Reporting Council, 2013: 13). Within the modest findings of previous research (Alexander, Buchholz, 1978, Aupperle, Carroll, Hatfield, 1984, Blackburn, Doran, Shrader, 1994, Orlitzky, Schmidt, Rynes, 2003, Peloza, 2009, Kapoor, Sandhu, 2010), it is confirmed that there is a strong interdependence and a positive correlation between CSR and business performance indicators. Recent research conducted by Kapoor and Sandhu (2010) on a sample of 93 companies in India confirmed that this type of empirical testing is usually in compliance with traditional business performance indicators. Therefore, there is a need to emphasize criticism stating that companies with better financial results can afford additional CSR investment. The complexity of such causality carries out the question whether investments in the direction of CSR improve company performance or the company's success is a strong predictor of CSR activities. This question can be further aggravated by issues of short time series that are present in empirical patterns of multiple previous researches and where it is not possible to give an ambiguous answer.

Theoretical and practical approach to value added in the sphere of sustainability has been a subject matter of research of a number of distinguished authors: Ball, Owen and Gray (2000), Hart and Milstein (2003), Graham and Bertels (2006), Ehrmann (2008) and Kuosmanen and Kuosmanen (2009). In their paper Hart and Milstein (2003) recognize different processes and forms of creating sustainability values as an aftermath of implementing CSR business strategies. This enhances by the research of Graham and Bertels (2006) considering that creation of sustainable value connects with development of management frameworks regarding the SVA 
measurement, analysis and control. Kuosmanen and Kuosmanen (2009) also distinguish SVA as a suitable integrative measure of rating company sustainable development. Kuosmanen and Kuosmanen criticize the content of the Figge-Hahns SVA model; however, they do not empirically confirm their critics by testing any of the TBL parameters included in the SVA calculation. Therefore, as not empirically proven, their critic is not significantly accepted. Along with the proposed SVA measure Ehrmann (2008: 1-3) suggests measurement of a company sustainability by using a simple analysis of values and indicators contained in the TBL and using the DEA method. Although these two proposals do not represent integrated assessment of company sustainability, Ehrmann's research confirms that any type of TBL analysis depends on availability of unified and consistent set of published CSR data. This again emphasizes standardized CSR reports as a reliable source of qualitative CSR data requested for the analysis of business sustainability. All the relevant issues of standardization and sources of TBL data can become minor when using the Sustainability Reporting Guidelines of the Global Reporting Initiative - GRI (2013). The mentioned guidelines integrate company's financial, environmental and social impacts. Aim of this paper is to test SVA as justified and relevant integrative sustainability measure that reflects financial, environmental and social business impacts. Such confirmation was not a subject of any previous scientific research. In this research crucial TBL parameters will be presented as relevant statistical variables and subjected to affirmative methodology and empirical data analysis in order to prove and explain integrative characteristics of the SVA.

\section{Methodology}

Application of the SVA presented by Figge and Hahn (2002) depends on the economic principles and investment logic, as an approach consisted of three key elements:

1. company eco-efficiency - implies efficient distribution and creation of socially valuable impacts in business operations,

2. opportunity costs - they occur if the value is created (or destroyed) by using a limited natural resource in a more (or less) effective manner than in other companies within the specific industry/sector (benchmark) and

3. benchmark analysis - intended for setting the price of capital (resources) engaged, respecting effective return on investment (ROI) for the specific industry (return to cost ratio).

Sustainability at a company level can be determined as a value added arisen by successfully managing the company Triple Bottom Line. This is crucial according to the Figge and Hahn who define that whenever economic growth exceeds the 
cost of compensation for any negative changes in eco-effectiveness the SVA is positive. Therefore, positive SVA occurs as long as economic growth exceeds the joint contributions to value creation of negative changes in effectiveness and ecoefficiency expressions. In other words, the cost of compensation for all additional environmental (EIAi) and social impacts (SIAj) sum up and then compare to economic growth. Figge and Hahn (2004a: 182) condition this by the following function:

$$
V A_{t 1}-V A_{t 0} \geq \frac{1}{n+m}\left(\sum_{i=1}^{n} E E_{i, b} \cdot\left(E I A_{i, t_{1}}-E I A_{i, t_{0}}\right)+\sum_{j=1}^{m} S E_{j, b} \cdot\left(S I A_{j, t_{1}}-S I A_{j, t_{0}}\right)\right)
$$

Where:

$V A_{t 1}=$ Value Added of the company in $t_{1}$

$V A_{t 0}=$ Value Added of the company in $t_{0}$

$n=$ number of relevant environmental impacts

$m=$ number of relevant social impacts

$E E_{i, b}=$ eco-efficiency of the benchmark for environmental resource $i$

$S E_{j, b}=$ social efficiency of the benchmark for social resource $j$

$E I A_{i, t 0}$ and $E I A_{i, t 1}=$ eco-effectiveness for environmental impact $i$ in $t_{0}$ and $t_{1}$

$S I A_{j, t 0}$ and $S I A_{j, t 1}=$ social effectiveness for social impact $j$ in $t_{0}$ and $t_{1}$

Respecting this, eco-efficiency and socio-efficiency occur as two main drivers of the long-term business sustainability. These two drivers arise from the microeconomic level of the single company and by the synergy of multiple companies (industry) they are being transmitted to the macroeconomic level. At the macroeconomic level, all contributions of individual companies inside one national economy generate GDP as a measure of economic growth (EG). At a company level, created value added determines comparative measure of such growth (EG). Value added is observed for a given period (previously indicated as $V A_{t 1} \mathrm{i} V A_{t 0}$ ), i.e. this is a company value added in time units $t_{1} \mathrm{i} t_{0}$. Thus, the economic growth of the company based on its value added is:

$$
E G=\left(V A_{t 1}-V A_{t 0}\right)
$$

Time component of value added $\left(t_{0} \mathrm{i} t_{1}\right)$ is a relevant parameter for measuring sustainability. In accordance with the premises of sustainable development, any type of sustainable value exist only when the company has achieved positive value added in comparison to the other companies in the same industry. Positive value added is generated only when the total consumption of each production resource is 
kept at the level of the previous production period $\left(\mathrm{t}_{0}\right)$ with a growing output during the same time. This interprets that integrative measure of a company efficiency in generating TBL sets in a specific form of sustainable value added (SVA). In this context, the structure of the SVA presents as follows (Figge, Hahn, 2004a: 182):

$$
S V A=E G-\frac{1}{n+m}\left(\sum_{i=1}^{n}\left(E G-S V A_{s i, i}\right)+\sum_{j=1}^{m}\left(E G-S V A_{s i, j}\right)\right)
$$

Figge and Hahn's model implies tracking derivations of any efficiency changes caused by different usage of environmental or social resources, which reduces sustainability parameters of economic growth. Negative changes of company effectiveness related to environmental and social impacts represent costs i.e. the reduction of value added along with its sustainability components. In this case SVA is being calculated as the difference of economic growth (EG) and costs that can cause adverse changes in effective realization of environmental $\left(S V A_{s i, i}\right)$ and social $\left(S V A_{s i, j}\right)$ effects. Any such change reduces the potentially achievable economic growth i.e. the potential value added of the company.

Methodology within the defined model conducts analysis of independent variables that affect two dependent variables - sustainable value added (SVA) and value added (VA). Respecting time series analysis, this research aims to answer the needs of introducing a systematic and standardized integral approach for measuring company success in terms of TBL and all of its financial and nonfinancial sustainability aspects. Reason for this approach is the evaluation of effects caused by changed methodology of a company performance measurement. The change of independent variables - financial, environmental, and variables of social responsibility (the TBL variables altogether) will have different impacts depending on the methodology used for measuring company financial performance or TBL performance. SVA as a business performance measure includes assessment mechanisms for environmental impacts. It also has a built-in aspect of social efficiency. These are corporate responsibility aspects like employee training, safety at work, co-operation with the local community, etc., which is opposed to traditional business performance measures/indicators that do not internalize set of nonfinancial variables. The methodological approach described in this paper should either confirm or deny, at a significant certainty level, the proposed hypothesis on the SVA as an integrative measure of business sustainability.

\section{Empirical data and analysis}

Executing empirical analysis of the SVA as an integrative measure of company sustainability to a large extent depends on available TBL data sources. This is especially due to the aforementioned issues of non-uniformed CSR reporting 
among companies and different industries. To realize the condition of Figge and Hahn's model that implies benchmark analysis, this research initially included different types of industries across different countries (financial services, energetic sector and energy utilities, food and beverage, mining, aviation, construction, media and metals products). Only benchmark analysis can ensure identification of eco-efficiency and socio-efficiency ratios. Companies subjected to analysis had to be production oriented to enable testing of the TBL variables (like energy and water consumption, GHG emissions and generated waste) along with the financial variables. Condition of production orientation eliminated subjects from financial services and media industry. For each industry, there was a data evaluation process with two basic empirical requests: 1) each company had to have minimally three CSR data periods (constant CSR reports during a three years' period) and 2) there had to be full transparency and availability of published CSR data. The last request regarding the presence of full CSR data was ensured by using the Sustainability Reporting Guidelines of the Global Reporting Initiative - GRI (2013). The GRI Guidelines dominate in sustainability reporting practice with their specific industrial reporting frameworks, which allowed successful TBL data collecting within the selected benchmark. In addition, there was a request regarding high sample quantity, not fulfilled in all of the analyzed sectors/industries. Based on the given sample settings only CSR reports of the companies from the food and beverage industry ensured a relevant sample (Table 1). Data sample included CSR reports from food and beverage industry for a 3 years' period starting from the year 2011 to 2013. The following issues defined this period of data series:

- SVA methodology used in the paper preconditions benchmark data to determine appropriate level of eco-efficiency and socio-efficiency. This means using exclusively CSR reporting model that reflects fixed period of time across companies in one benchmark (the GRI Guidelines).

- Only the companies included in the database of the Global Reporting Initiative (GRI Database) had compliant G3 versions of reporting standards in a period from 2011 to 2013 (and the so-called Guidelines before 2011). Therefore, the period of $2011-2013$ was the only logical one to be submissive for further analysis. This is because introducing the G4 GRI Guidelines after the 2013, while at the same time some of the companies continued to use versions of the G3 Guidelines. This caused significant differences in benchmark CSR data. Therefore, to avoid data set differences the data from the period of 2011 - 2013 was used in terms of standardization and preconditioned by the request of benchmark analysis (this is also advocated by financial investing policies and opportunity costs analysis, discussed by Figge-Hahn 2004a: 179-181). 
Dejan Miljenović • Testing sustainable value added as an integrative measure of business...

Table 1: Structure of observations according to the country of residence

\begin{tabular}{|c|c|c|c|c|}
\hline No. & Country & $\begin{array}{l}\text { Existence of mandatory } \\
\text { CSR reporting }\end{array}$ & $\begin{array}{l}\text { Number of } \\
\text { companies }\end{array}$ & $\begin{array}{c}\text { Number of panel } \\
\text { observations }\end{array}$ \\
\hline 1 & Australia & Yes & 1 & 3 \\
\hline 2 & $\begin{array}{l}\text { Bosnia and } \\
\text { Herzegovina }\end{array}$ & No & 1 & 3 \\
\hline 3 & Brazil & Yes & 2 & 6 \\
\hline 4 & Denmark & Yes & 1 & 3 \\
\hline 5 & France & Yes & 5 & 15 \\
\hline 6 & Croatia & No & 10 & 30 \\
\hline 7 & Ireland & $\begin{array}{l}\text { No- except for financial } \\
\text { institutions that report on CSR }\end{array}$ & 1 & 3 \\
\hline 8 & Italy & Yes & 2 & 6 \\
\hline 9 & Israel & Law proposal in process & 1 & 3 \\
\hline 10 & South Africa & Yes & 1 & 3 \\
\hline 11 & Canada & Yes & 1 & 3 \\
\hline 12 & Mexiko & Yes & 2 & 6 \\
\hline 13 & Netherlands & Yes & 3 & 9 \\
\hline 14 & Norway & Yes & 1 & 3 \\
\hline 15 & Germany & $\begin{array}{l}\text { No - only voluntary ethics } \\
\text { and CSR code application }\end{array}$ & 5 & 15 \\
\hline 16 & Serbia & No & 2 & 6 \\
\hline 17 & Spain & Yes & 2 & 6 \\
\hline 18 & \begin{tabular}{|l|} 
Sweden \\
\end{tabular} & Yes & 1 & 3 \\
\hline 19 & Switzerland & Yes & 2 & 6 \\
\hline 20 & Great Britain & Yes & 6 & 18 \\
\hline \multicolumn{3}{|l|}{ Total } & 50 & 150 \\
\hline
\end{tabular}

Source: Author's research

Characteristics of the sample define the model of empirical research used in this paper. Sample is consisted of 150 data panels in a 3 years' period. It is a data panel of short time series and numerous companies. The common researcher's dilemma regarding the panel regression models refers to choosing a model of fixed or random effects. Model of fixed effects usually applies when the data pattern includes relatively long time series and when autocorrelation exists within the selected data set (conditioned by certain common characteristics of the company, country, tax system etc.) In the case of data sample where a panel consists of a larger number of research subjects, and the time series is shorter, it is preferable to give advance to the model of random effects. The given data sample consists of a large number of companies from specific sector (food and beverages). The sample contains data 
from eight sub sectors across different countries. Therefore, a set of data in this research has the features of a random choice sample. The panel regression model used in this paper is as follows:

$$
y_{i t}=F P_{i t} \beta+O P_{i t} \gamma+D O P_{i t} \delta+a_{i}+u_{i t} \text { za } t=1, \ldots, T \text { and } i=1, \ldots, N
$$

where:

$y_{i t}=$ dependent variable representing the company business result (Sustainable Value Added or Value Added) per individual company and time $t$,

$F P_{i t} \beta=$ matrix of independent financial variables with the corresponding coefficient $\beta$, $O P_{i t} \gamma^{\prime}=$ matrix of independent environmental variables with the corresponding coefficient $\gamma$,

$D O P_{i t} \delta=$ matrix of the independent social variables with the corresponding coefficient $\delta$,

$a_{i}=$ denotes specific factors characteristic of each country and

$u_{i t}=$ the case of a random deviation.

The matrix of independent financial variables $\left(F P_{i t} \beta\right)$ includes values of VA, gross profit, gross revenues, financial revenues, EBIT, EBITDA, long-term assets, shortterm assets, capital, long-term liabilities, short-term liabilities and long-term debt. Matrix of independent environmental variables $\left(O P_{i t} \gamma\right)$ includes values of GHG emissions (in tons of $\mathrm{CO}^{2}$ equivalent), consumed energy (in $\mathrm{kWh}$ ), consumed water (in $\mathrm{m}^{3}$ ), and generated waste (in tons). Matrix of the independent social variables $\left(D O P_{i t} \delta\right)$ represents "dummy variables" of different CSR aspects including:

D1 - Program/value of employee education/training,

D2 - Average hours of education/training per year per employee,

D3 - Program/value of safety at work,

D4 - Lost work days due to injuries at work (per million working hours),

D5 - Percentage of women in the governing bodies,

D6 - Value/existence of investments in local community,

D7 - Programs realized in cooperation with the local community bodies,

D8 - Value/existence of donations,

D9 - Policies of corporate governance,

D10 - GRI index,

D11 - GRI Level Check - indicates existence of full TBL data within the GRI report. 
Value of the SVA as a dependent variable was separately calculated. Chosen social variables represent diversity of company respecting the norms of gender equality, safety at work, engagement and cooperation with the community in general.

This part of the paper explains the results obtained by the application of the elaborated panel regression model. It is important to emphasize that the characteristics of the sample, analysis of the descriptive statistics and the correlation analysis define final form of the econometric analysis method - panel regression analysis of random effects. This approach generated multiple model specifications with respect to the elimination of part of the financial variables. Tables 2 and 3 represent results of the analysis within the five model specifications. It is important to notice that a Table 2 represents results of the empirical analysis of a Value Added (VA) as a dependent variable, where in Table 3 Sustainable Value Added (SVA) is set as dependent variable. Distinguishing effects of the independent variables on dependent variables (VA and SVA) is of crucial importance for proving the underlying research hypothesis. VA as a performance measure primarily incorporates financial business results. Therefore, VA serves as a traditional concept of measuring company's performance without indulging fundamental CSR proposition: business results integrated in the Triple Bottom Line. Assumption is that the testing of the SVA should provide the evidence of successful integration of financial performances with company environmental and social performances within the SVA as a measure. SVA marks the methodological shift from measuring results based exclusively on economic growth toward measuring achievements of sustainable development, which embodies an integral approach for measuring holistic business performance. At the same time, the mentioned research of business sustainability indicators (Herzig, Schaltegger, 2006, Figge, Hahn, 2002, Olsthoorn et al. 2001, Lyrstedt, 2005, Veleva, Ellenbecker, 2001, Petrini, Pozzebon, 2009) does not simultaneously test the effects of environmental and social variables on traditional performance indicators or integrated performance indicators, as it is the case with VA and SVA in this paper. This comparison is done separately for traditional performance indicators (Table 2 for VA) and for integrated performance indicators (Table 3 for SVA). 
Dejan Miljenović • Testing sustainable value added as an integrative measure of business... Zb. rad. Ekon. fak. Rij. • $2018 \cdot$ vol. $36 \cdot$ no. $1 \cdot 155-181$

Table 2: Effects of environmental, financial and social responsibility variables on the growth of the VA

\begin{tabular}{|c|c|c|c|c|c|}
\hline Dependent & & & Value Added & & \\
\hline $\begin{array}{l}\text { Independent } \\
\text { variables }\end{array}$ & Model 1 & Model 2 & Model 3 & Model 4 & Model 5 \\
\hline GHG emissions & $\begin{array}{r}0.1089968 \\
1.57\end{array}$ & $\begin{array}{r}0.0596903 \\
0.82\end{array}$ & $\begin{array}{r}0.1008391 \\
0.156\end{array}$ & & $\begin{array}{r}0.0548515 \\
0.73\end{array}$ \\
\hline Energy & $\begin{array}{r}0.2137392 \\
2.13 * *\end{array}$ & $\begin{array}{r}0.1940935 \\
2.07 * *\end{array}$ & $\begin{array}{r}0.2741058 \\
(2.71)^{* * *}\end{array}$ & & $\begin{array}{r}0.2295722 \\
2.31 * *\end{array}$ \\
\hline Water & $\begin{array}{r}-0.0503407 \\
-0.79\end{array}$ & \begin{tabular}{|r|}
-0.0710805 \\
-1.14
\end{tabular} & $\begin{array}{r}-0.0270501 \\
-0.42\end{array}$ & & $\begin{array}{r}-0.0542517 \\
(-0.83)\end{array}$ \\
\hline Waste & $\begin{array}{r}0.070091 \\
1.15\end{array}$ & \begin{tabular}{|r|}
0.1467187 \\
$2.00 * *$ \\
\end{tabular} & \begin{tabular}{|r|}
0.0143412 \\
0.23
\end{tabular} & & $\begin{array}{r}0.0769953 \\
(0.93)\end{array}$ \\
\hline Financial revenues & & $\begin{array}{r}0.0257022 \\
0.84\end{array}$ & & $\begin{array}{r}0.0429246 \\
(1.20)\end{array}$ & $\begin{array}{r}0.0356884 \\
(1.09)\end{array}$ \\
\hline Capital & & $\begin{array}{r}0.2209246 \\
3.30 * * *\end{array}$ & & $\begin{array}{r}0.2776852 \\
(3.72)^{* * *}\end{array}$ & $\begin{array}{r}0.225542 \\
3.14 * * *\end{array}$ \\
\hline Long term debt & & $\begin{array}{r}0.0215683 \\
1.29\end{array}$ & & $\begin{array}{r}0.0321109 \\
1.71^{*}\end{array}$ & $\begin{array}{r}-0.0980211 \\
-0.87\end{array}$ \\
\hline D1 & & & $\begin{array}{r}-0.1918357 \\
-1.52\end{array}$ & $\begin{array}{r}-0.1791497 \\
(-1.50)\end{array}$ & $\begin{array}{r}-0.0980211 \\
(-0.87)\end{array}$ \\
\hline D2 & & & $\begin{array}{r}0.1212026 \\
(1.03)\end{array}$ & $\begin{array}{r}0.1009433 \\
0.91\end{array}$ & $\begin{array}{r}0.0965887 \\
0.98\end{array}$ \\
\hline D3 & & & $\begin{array}{r}-0.10201 \\
(-1.04)\end{array}$ & $\begin{array}{r}0.0647001 \\
0.67\end{array}$ & $\begin{array}{r}0.0055191 \\
0.06\end{array}$ \\
\hline D4 & & & $\begin{array}{r}0.0100897 \\
(0.08)\end{array}$ & $\begin{array}{r}0.1380804 \\
1.10\end{array}$ & $\begin{array}{r}0.098532 \\
0.88\end{array}$ \\
\hline D5 & & & $\begin{array}{r}-0.1793056 \\
(-1.64)\end{array}$ & $\begin{array}{r}0.0154438 \\
0.13\end{array}$ & $\begin{array}{r}0.0073574 \\
0.07\end{array}$ \\
\hline D6 & & & $\begin{array}{r}0.1255405 \\
(1.05)\end{array}$ & $\begin{array}{r}0.1349447 \\
1.16 \\
\end{array}$ & \begin{tabular}{|r|}
0.0946648 \\
0.92 \\
\end{tabular} \\
\hline D7 & & & $\begin{array}{r}-0.308547 \\
(-1.73)^{* *}\end{array}$ & $\begin{array}{r}-0.2226077 \\
-1.27\end{array}$ & $\begin{array}{r}-0.2334875 \\
-1.49\end{array}$ \\
\hline D8 & & & $\begin{array}{r}-0.1455707 \\
(-1.05)\end{array}$ & $\begin{array}{r}-0.1924517 \\
-1.39\end{array}$ & $\begin{array}{r}-0.2111592 \\
-1.73\end{array}$ \\
\hline D9 & & & $\begin{array}{r}-0.1160835 \\
(-0.69)\end{array}$ & $\begin{array}{r}-0.0471391 \\
(-0.27)\end{array}$ & $\begin{array}{r}-0.0780914 \\
-0.49\end{array}$ \\
\hline D10 & & & $\begin{array}{r}-0.1361315 \\
(-1.25)\end{array}$ & $\begin{array}{r}-0.3034904 \\
(-2.78)^{* * *}\end{array}$ & $\begin{array}{r}-0.1953971 \\
-1.93 * * *\end{array}$ \\
\hline D11 & & & $\begin{array}{r}0.2877464 \\
(2.84) * * *\end{array}$ & $\begin{array}{r}0.2364489 \\
(2.34)^{* * *}\end{array}$ & $\begin{array}{r}0.2347481 \\
(2.59) * * *\end{array}$ \\
\hline Constant & $\begin{array}{r}15.74337 \\
(1.97)^{* *}\end{array}$ & $\begin{array}{r}5.564311 \\
4.01 * * *\end{array}$ & $\begin{array}{l}8.247965 \\
(6.78)^{* * *}\end{array}$ & $\begin{array}{l}8.511355 \\
(8.63)^{* * *}\end{array}$ & $\begin{array}{l}5.81979 \\
3.95 * * *\end{array}$ \\
\hline
\end{tabular}


Dejan Miljenović • Testing sustainable value added as an integrative measure of business...

\begin{tabular}{|l|r|r|r|r|r|}
\hline & \multicolumn{5}{|c|}{$\begin{array}{c}\text { Dependent } \\
\text { variable }\end{array}$} \\
\cline { 3 - 7 } $\begin{array}{l}\text { Independent } \\
\text { variables }\end{array}$ & Model 1 & Model 2 & Model 3 & Model 4 & Model 5 \\
\hline Opservations (n) & 140 & 112 & 139 & 115 & 111 \\
\hline Groups & 49 & 42 & 49 & 44 & 42 \\
\hline $\mathrm{R}^{2}$ (within) & 0,02 & 0,13 & 0,15 & 0,21 & 0,28 \\
\hline $\mathrm{R}^{2}$ (between) & 0,41 & 0,47 & 0,48 & 0,21 & 0,53 \\
\hline $\mathrm{R}^{2}$ (total) & 0,43 & 0,51 & 0,49 & 0,42 & 0,56 \\
\hline
\end{tabular}

Note 1: $* * *, * * *$ indicate the level of statistical significance of $10 \%, 5 \%$ and $1 \%$

Note 2: "Dummy variables" representing different CSR aspects: D1-Program/value of employee education/training, D2-Average hours of education/training per year per employee, D3-Program/value of safety at work, D4-Lost work days due to injuries at work (per million working hours), D5-Percentage of women in the governing bodies, D6-Value/ existence of investments in local community, D7-Programs realized in cooperation with the local community bodies, D8-Value/existence of donations, D9-Policies of corporate governance, D10-GRI index, D11-GRI LevelCheck.

Source: Author's calculation

In terms of environmental variables and their effects, results of the regression analysis shown in Table 2 indicate that energy consumption highly and significantly affects the increase of the company VA. To a somewhat lower extent, environmental variables also affect the increase of waste, which has significant value in only one specification. Water consumption and emissions of GHG pollutants are neutral to business performance in this model. Explanation of obtained results is that increased production causes higher energy consumption and additional creation of waste. Because of this, the cost of the mentioned energy inputs and waste outputs is significantly lower than the created VA, which consequently enables the creation of positive financial result. In this case, the energy consumption and generating waste positively contribute to VA. The neutrality that is set forth-in terms of GHG emissions and water consumption may indicate that these costs are not internalized, meaning that the manufacturer doesn't pay the price of such pollution (through emission taxes or fees). On the other hand, the volume of GHG emissions and water consumption seems to be somewhat internalized by restrictive regulation regarding the GHG emissions, by conservation of water resources or by the wastewater treatment policies that are included in company costs. This is the specific case with the level of water consumption due to the negative coefficient value; however, it does not have a high statistical significance.

When it comes to the assessment of effects that financial variables have on business performance, there is a positive impact of the owned capital. However, in this case, it is highly difficult to determine whether companies of better performance have 
higher capital or there is a presumption that high levels of capital become predictor of better performance and, therefore, this result in a lower use of the external capital sources, which implies lower financial leverage.

The conducted analysis of different CSR variables (D1 - D11) indicates negative coefficient values for most of the variables. This leads to the conclusion that such investments represent a pure business cost when assessed by traditional performance indicator of VA. However, most of the values are not statistically significant, except for the aggregate GRI index. In this case, investment programs in the local community in one specification have a significant and negative value. It is interesting that there is a negative value of the GRI index while the GRI LevelCheck is positive and significant. This clues some of the related research (Peloza, Papania, 2008, Lii, Lee, 2012, Maistriau, Bonardi, 2014 and Salaiz, 2015) that generally prove relevance of CSR regarding company reputation that may have an indirect positive impact on financial performance.

Table 3: Effects of environmental, financial and social responsibility variables on the growth of the SVA

\begin{tabular}{|c|c|c|c|c|c|}
\hline \multirow{2}{*}{$\begin{array}{l}\begin{array}{l}\text { Dependent } \\
\text { variablependent } \\
\text { variables }\end{array} \\
\text { variables }\end{array}$} & \multicolumn{5}{|c|}{ Sustainable Value Added } \\
\hline & Model 1 & Model 2 & Model 3 & Model 4 & Model 5 \\
\hline GHG emissions & $\begin{array}{l}-1.911051 \\
(-2.68) * * *\end{array}$ & $\begin{array}{r}-1.991017 \\
-2.64 * * * \\
\end{array}$ & $\begin{array}{r}-1.826432 \\
(-2.46)^{* *} \\
\end{array}$ & & $\begin{array}{r}-1.739446 \\
-2.17 * * \\
\end{array}$ \\
\hline Energy & $\begin{array}{r}0.3700886 \\
(0.79)\end{array}$ & $\begin{array}{r}0.401665 \\
0.84\end{array}$ & $\begin{array}{r}0.2893909 \\
(0.59)\end{array}$ & & $\begin{array}{r}0.342198 \\
0.68\end{array}$ \\
\hline Water & $\begin{array}{r}0.9650315 \\
(1.62) \\
\end{array}$ & $\begin{array}{r}1.748811 \\
3.19 * * * \\
\end{array}$ & $\begin{array}{r}1.147504 \\
(1.95)^{* *}\end{array}$ & & $\begin{array}{r}1.809092 \\
3.35 * * * \\
\end{array}$ \\
\hline Waste & $\begin{array}{r}-0.7840885 \\
(-1.49) \\
\end{array}$ & $\begin{array}{r}-2.018239 \\
-3.84 * * * \\
\end{array}$ & $\begin{array}{r}-1.003918 \\
(-1.86)^{*} \\
\end{array}$ & & $\begin{array}{l}-2.25482 \\
-4.15 * * * \\
\end{array}$ \\
\hline Financial revenues & & $\begin{array}{r}0.1365616 \\
0.31\end{array}$ & & $\begin{array}{r}-0.2839207 \\
-0.60\end{array}$ & $\begin{array}{r}0.2445557 \\
0.52\end{array}$ \\
\hline Capital & & $\begin{array}{r}1.844458 \\
(4.02)^{* * *}\end{array}$ & & $\begin{array}{r}1.219689 \\
2.26 * * \\
\end{array}$ & $\begin{array}{r}1.884316 \\
4.09 * * *\end{array}$ \\
\hline Long term debt & & $\begin{array}{r}0.4216891 \\
(1.60)\end{array}$ & & $\begin{array}{r}0.2159537 \\
0.72\end{array}$ & $\begin{array}{r}0.4475285 \\
1.57\end{array}$ \\
\hline D1 & & & $\begin{array}{r}-0.4842321 \\
(-0.27) \\
\end{array}$ & $\begin{array}{r}1.948622 \\
0.92 \\
\end{array}$ & $\begin{array}{r}-0.5463569 \\
-0.26 \\
\end{array}$ \\
\hline D2 & & & $\begin{array}{r}0.2151433 \\
(0.13) \\
\end{array}$ & $\begin{array}{r}-1.486774 \\
-0.80 \\
\end{array}$ & $\begin{array}{r}-0.1670527 \\
-0.09 \\
\end{array}$ \\
\hline D3 & & & $\begin{array}{r}-1.13279 \\
(-0.79) \\
\end{array}$ & $\begin{array}{r}-0.5205125 \\
-0.29 \\
\end{array}$ & $\begin{array}{r}0.2178453 \\
0.13 \\
\end{array}$ \\
\hline D4 & & & $\begin{array}{r}-1.63052 \\
(-0.91)\end{array}$ & $\begin{array}{r}-2.234874 \\
-1.06\end{array}$ & $\begin{array}{r}-0.6375291 \\
-0.32\end{array}$ \\
\hline
\end{tabular}


Dejan Miljenović • Testing sustainable value added as an integrative measure of business...

\begin{tabular}{|c|c|c|c|c|c|}
\hline Dependent & & Susta & inable Value $\mathrm{A}$ & ded & \\
\hline $\begin{array}{l}\text { Independent } \\
\text { variables }\end{array}$ & Model 1 & Model 2 & Model 3 & Model 4 & Model 5 \\
\hline D5 & & & $\begin{array}{r}-0.4174143 \\
-0.29 \\
\end{array}$ & $\begin{array}{r}1.133873 \\
0.63 \\
\end{array}$ & $\begin{array}{r}1.218365 \\
0.74 \\
\end{array}$ \\
\hline D6 & & & $\begin{array}{r}-0.1041943 \\
-0.06\end{array}$ & $\begin{array}{r}-1.704915 \\
-0.85\end{array}$ & $\begin{array}{r}-0.2220342 \\
-0.11\end{array}$ \\
\hline D7 & & & $\begin{array}{r}-1.39564 \\
-0.60\end{array}$ & $\begin{array}{r}-1.749175 \\
-0.65\end{array}$ & $\begin{array}{r}-1.659615 \\
-0.67\end{array}$ \\
\hline D8 & & & $\begin{array}{r}-0.3430855 \\
-0.20\end{array}$ & $\begin{array}{r}-1.677648 \\
-0.81\end{array}$ & $\begin{array}{r}-1.932765 \\
-1.00\end{array}$ \\
\hline D9 & & & $\begin{array}{r}-1.203468 \\
-0.55\end{array}$ & $\begin{array}{r}-1.736924 \\
-0.67\end{array}$ & $\begin{array}{r}-1.233027 \\
-0.53\end{array}$ \\
\hline D10 & & & $\begin{array}{r}-1.005672 \\
-0.66\end{array}$ & $\begin{array}{r}0.3682527 \\
0.20\end{array}$ & $\begin{array}{r}-2.230696 \\
-1.25\end{array}$ \\
\hline D11 & & & $\begin{array}{r}1.478386 \\
1.03\end{array}$ & $\begin{array}{r}2.114942 \\
1.23\end{array}$ & $\begin{array}{r}2.973475 \\
1.82 *\end{array}$ \\
\hline Constant & $\begin{array}{r}15.74337 \\
(1.97)^{* *}\end{array}$ & $\begin{array}{r}-8.785121 \\
(-1.01) \\
\end{array}$ & $\begin{array}{r}20.82727 * * \\
2.35 \\
\end{array}$ & $\begin{array}{r}-5.684693 \\
-0.68 \\
\end{array}$ & $\begin{array}{r}-7.063795 \\
(-0.71) \\
\end{array}$ \\
\hline Opservations (n) & 144 & 116 & 143 & 119 & 115 \\
\hline Groups & 49 & 42 & 49 & 44 & 42 \\
\hline $\mathrm{R}^{2}$ (within) & 0,04 & 0,01 & 0,03 & 0,00 & 0,01 \\
\hline $\mathrm{R}^{2}$ (between) & 0,17 & 0,57 & 0,29 & 0,33 & 0,66 \\
\hline $\mathrm{R}^{2}$ (total) & 0,16 & 0,56 & 0,27 & 0,33 & 0,64 \\
\hline
\end{tabular}

Note $1: *, * *, * * *$ indicate the level of statistical significance of $10 \%, 5 \%$ and $1 \%$

Note 2: "Dummy variables" representing different CSR aspects: D1-Program/value of employee education/training, D2-Average hours of education/training per year per employee, D3-Program/value of safety at work, D4-Lost work days due to injuries at work (per million working hours), D5-Percentage of women in the governing bodies, D6-Value/ existence of investments in local community, D7-Programs realised in cooperation with the local community bodies, D8-Value/existence of donations, D9-Policies of corporate governance, D10-GRI index, D11-GRI LevelCheck.

Source: Authors calculation

As noted, Table 3 represents interdependence results for the groups of financial, environmental and social responsibility variables in relation to the dependent variable of SVA. In the case of SVA as an independent variable, there are significantly different results of analysis in comparison to the VA. This is especially the case when it comes to the effects of environmental variables. Namely, the GHG emissions and generated waste record extremely high negative and statistically significant values of their coefficients. In other words, the measurement concept of 
SVA highlights and integrates extremely negative developmental effects of GHG emissions and waste pollution. On the other hand, values of energy and water consumption are extremely positive and, in the case of water consumption, they are statistically significant. The results of conducted analysis confirm significant difference of environmental variables effects in relation to the selected dependent variables. Traditional performance metrics in the case of VA includes the effects of environmental variables only through company costs while the concept of SVA successfully integrates non-financial effects, previously excluded within the traditional VA approach. This confirms SVA as an integrative sustainability measure, assumed by the initial hypothesis of this paper.

$\mathrm{R}^{2}$ specification values in Table 3 may be stated as low, although, this is not the case, except in the case of within regression that explains relations between dependent and independent variable across time. This within $R^{2}$ is low because testing included several dummy variables which did not explain relationship between dependent and independent variable across the given time period. For example, in a case of one company analysis these values are 0 or 1 . However, when conducting analysis between more companies ( $R^{2}$ between) than this $\mathrm{R}^{2}$ is high because in this case socially responsible companies (represented by dummy 1 ) compare to companies that are not socially responsible -0 . This explains the logic of (sustainable) value added-SVA, which was the research objective of the paper i.e. to conduct testing between a significant numbers of companies within one industry (the benchmark).

Regarding the effects of financial variables, the results in Table 3 are consistent. Only the variable of capital has positive and statistically significant effects in listed specifications of the model. The equal conclusions can be set when it comes to CSR variables. It appears that only a set of socially responsible business practices presented by the variable of GRI LevelCheck leads to statistically significant and positive effects of company sustainable development. Moreover, this is worth in both cases when measuring business performance/success by a traditional VA approach or by proposed SVA methodology.

\section{Results and discussion}

The conducted research resulted in two basic findings. The first finding shows statistically significant differences when business performance is measured by traditional or by integrative measures. The second finding is that the SVA model successfully integrates theoretically defined TBL parameters promoted by the CSR theories, TBL framework and business sustainability management. The additional conclusion relates to the collection of the TBL data. Namely, for research purposes, the author used only the data provided by companies whose CSR reports where published in compliance with the Guidelines of the Global Reporting Initiative 
(GRI). The application of this method ensured a full presence of the TBL data primarily relevant for the calculation of the SVA. Otherwise, environmental or social data may be extremely hard to collect due to a lack of standardized reporting. There are still companies that do not include these aspects of doing business. However, there is just a small number of such cases. Standardized GRI reports ensure and maintain data transparency for analytically relevant period of time, which was essential for SVA calculation and testing within this paper. Foremost, GRI reports provide quantified data sources. Expression of this data within the paper included $\mathrm{kWh}$ for energy consumption, $\mathrm{m}^{3}$ for water usage and drainage, tons (t) for different types of waste like paper, plastics etc., which ensured exact determination of eco-efficiency parameters for companies from the sample. Results of testing financial variables on the growth of SVA in Table 3 confirmed not only the relevancy of the SVA for separate analysis of non-financial business aspects. Empirical results also confirm SVA as a practical and reliable indicator in terms of financial sustainability. Precondition for this type of measurement is that financial results link to environmental and social results. Therefore, the company management has an obligation to analyze financial performance using indicators of eco-efficiency and socio-efficiency. To obtain this link standardized using CSR reports was obligate. Environmental and social efficiency ratings from the food and beverages benchmark derived from the CSR reports of all included companies.

Research findings reveal disadvantages in the case of VA in terms of negative effects related to environmental variables. This is especially for energy usage and waste generation. However, as a traditional financial performance measure VA respects and internalizes GHG emission costs along with the water inputs. This is because of existing international regulation on pollution and applied standards of the wastewater treatment in recent decades. Results in this part indicate that energy and waste efficiency ratios are still present in general analysis of company performance and its sustainability. Although environmental variables can also express in terms of costs, the purpose of the research was to enter these variables in the model as quantitative non-financial values. The meaning of the SVA model is to integrate non-financial variables with financial ones. This also applies for social variables from D1 to D9 that entered the model as quantitative variables expressed in lost work days/hours, percentages, values and number of socially responsible projects. This way the ultimate objective was to integrate non-financial variables with financial ones and to measure them using the SVA and VA. Research result draws attention to the insufficiency of sustainability content within the traditional performance measures (VA). Every industry has a specific set of parameters affecting its efficiency ratios. These ratios are extremely relevant in application of environmental and social indicators, which provides feedbacks on the company sustainability performance and add up to traditional financial indicators. This initiates rethinking business analysis process where financial indicators always take the lead. 
Internal and external sustainability aspects are crucial in managing issues of business sustainability. As research predictors these aspects need to be theoretically and empirically observed. This was done using the TBL model for managing business sustainability issues. The relevance of this research is also that it used data collected exclusively from the GRI Guidelines. Guidelines represent a standard frame for unifying financial, environmental and social data in one place - the CSR report. By doing this, the research promotes the importance of GRI Guidelines and confirms them as a basic and a transparent source of TBL information in any type of sustainability analysis. Model specifications given in this paper may modify according to management or stakeholder needs. Such flexibility is a significant benefit within the SVA model because different companies have different stakeholder interests and sustainability effects.

\section{Conclusion}

Relevant significance and a positive "reaction" of environmental and social variables on introducing SVA indicates possibility of deriving new measures of sustainability management. Research results did not diminish the relevance of financial variables, which was present in both cases, of the VA and the SVA, indicating permanent financial background. However, results of the SVA testing have confirmed that financial background successfully integrates with the variables of environmental and social sustainability. This is exclusively the case of the SVA measure, while it was not the case with the VA measure. In the case of nonfinancial variables, VA positively recognizes only energy consumption and waste as production inputs while GHG emissions and water usage become internalized as costs i.e. VA recognizes them exclusively on financial basis.

Research results have multipurpose implications in practice. Business analysts can go beyond financial risks, to measure and report on environmental and social risk aspects. Managers can "stern" company value by managing the balance between financial, environmental and social variables of the analyzed type of value added (VA or SVA). Furthermore, objectives related to economic values expand to additional value generators in the area of business environmental and social effects (given in the proposed SVA model). Therefore, this research raised SVA as a scientifically tested measure for linking all the relevant aspects of full business-to-society sustainability along with their efficiency ratios. Foremost, SVA stands as a core research issue of contemporary CSR management that simultaneously struggles with environmental and equality issues of modern business and society. Today, more and more investors, partners, financial institutions and social stakeholders base their company related decisions on company's non-financial effects. In this situation, sustainability measures supplement traditional performance indicators, which are no longer sufficient for holistic process of business decision-making. 
Future research objectives may confront sustainability management issues in a way to modify SVA and related indicators by the current needs of a certain company, market and stakeholder environment. The second research option is to move SVA in the area of managing stakeholder's relations and to use it as an indicator of stakeholder satisfaction. Another research path is to set for conducting empirical research in the area of recognizing advantages and relevance of sustainability reporting - the so-called CSR reports. CSR reporting and its development goes along with the development of the CSR performance measurement system. Interest for these types of research develops because managers and investors increasingly use non-financial data along with the financial ones to gain holistic views on business risks, especially those related to environment and society. Moreover, standardized CSR reporting eliminates the issue of TBL data transparency and availability. Future research definitely derives in a sense of further development and testing integrative sustainability measures. Generally, future mainstream research thesis should indulge acceptance of integrative metrics in the field of business sustainability.

\section{References}

Alexander, G. J., Buchholz R. A. (1978) "Corporate social responsibility and stock market performance", Academy of Management Journal, Vol. 21, No. 3, pp. 479-486, doi: 10.5465/255728.

Aupperle, K. E., Carroll, A. B., Hatfield, J. D. (1985) “An empirical investigation of the relationship between corporate social responsibility and profitability" Academy of Management Journal, Vol. 28, No. 2, pp. 446-463, doi: 10.2307/256210.

Ball, A., Owen, D. L., Gray, R. (2000) "External transparency or internal capture? The role of third-party statements in adding value to corporate environmental reports", Business Strategy and the Environment, Vol. 9, No. 1, pp. 1-23, doi: 10.1002/(sici)1099-0836(200001/02)9:1\%3C1::aid-bse227\%3E3.0.co;2-h.

Blackburn, V. L., Doran, M., Shrader, C. B. (1994) "Investigating the dimensions of social responsibility and the consequences for corporate financial performance", Journal of Managerial Issues, Vol. 6, No. 2, pp. 195-212.

Brammer, S., Jackson, G., Matten, D. (2012) "Corporate Social Responsibility and institutional theory: new perspectives on private governance", Socio-Economic Review, Vol. 10, No. 1, pp. 3-28, doi: 10.1093/ser/mwr030.

Bridoux, F., Stoelhorst, J. W. (2016) "Stakeholder Relationships and Social Welfare: A Behavioral Theory of Contributions to Joint Value Creation", Academy of Management Review, Vol. 41, No. 2, pp. 229-251, doi: 10.5465/amr.2013.0475. Campbell, J. L. (2007) "Why Would Corporations Behave in Socially Responsible Ways? An Institutional Theory of Corporate Social Responsibility", Academy of Management Review, Vol. 32, No. 3, pp. 946-967, doi: 10.5465/amr.2007. 25275684 . 
Dyllick, T., Hockerts, K. (2002) "Beyond the Business Case for Corporate Sustainability", Business Strategy and the Environment, Vol. 11, No. 2, pp. 130-141, doi: 10.1002/bse.323.

Ehrmann, M. (2008) “Comparing Sustainable Value Approach: Data Envelopment Analysis and indicator approaches - An application on German dairy farms". In 12th Congress of the European Association of Agricultural Economists (EAAE), August $26^{\text {th }}-29^{\text {th }}$, Ghent, Belgium: EAAE, pp. 1-14.

Elkington, J. (1997) Cannibals with Forks: The Triple Bottom Line of 21st Century Business, Oxford: Capstone Publishing Limited.

Esty, D. C., Winston, A. S. (2006) Green to gold, New Haven and London: Yale University Press.

Figge, F., Hahn, T. (2002) "Sustainable Value Added". In 10th International Conference of the Greening of Industry Network, June 2002, Göteborg, Sweden: School of Economics and Commercial Law at Göteborg University and the Centre for Environment and Sustainability at Chalmers University of Technology, pp. 1-25.

Figge, F., Hahn, T. (2004a) "Sustainable Value Added: measuring corporate contributions to sustainability beyond eco-efficiency", Ecological Economics, Vol. 48, No. 2, pp. 173-187, doi: 10.1016/j.ecolecon.2003.08.005.

Figge, F., Hahn, T. (2004b) "Value-oriented impact assessment: the economics of a new approach to impact assessment", Journal of Environmental Planning and Management, Vol. 47, No. 6, pp. 921-941, doi: 10.1080/0964056042000284901.

Figge, F., Hahn, T. (2005) "The Cost of Sustainability Capital and the Creation of Sustainable Value by Companies", Journal of Industrial Ecology, Vol. 9, No. 4, pp. 47-58, doi: 10.1162/108819805775247936.

Figge, F., Hahn, T. (2006) “Looking for Sustainable Value" Environmental Finance, Vol. 7, No. 8, pp. 34-35, doi: 10.1787/19901135.

Figge, F., Hahn, T. (2009) "Not measuring sustainable value at all: A response to Kuosmanen and Kuosmanen", Ecological Economics, Vol. 69, No. 2, pp. 244249, doi: 10.1016/j.ecolecon.2009.08.003.

Frederick, W. C., Post, J. E., Davis, K. (1992) Business and society: corporate strategy, public policy, ethics, $7^{\text {th }}$ ed., New York: McGraw Hill.

Freeman, R. E. (1984) Strategic Management: A Stakeholder Approach, Marshfield: Pitman Publishing Inc, doi: 10.1017/cbo9781139192675.003.

Friedman, M. (1970) "The social responsibilitiy of business is to increase profits", The New York Times Magazine, $13^{\text {th }}$ September 1970, doi: 10.1007/978-3-54070818-6_14.

Graham, R., Bertels, S. (2006) "Achieving Sustainable Value: Sustainability Portfolio Assessment", Greener Management International, No. 54, pp. 57-67, doi: 10.9774/gleaf.3062.2006.su.00010. 
Global Reporting Initiative - GRI (2013) Sustainability Reporting Guidelines G4: Reporting Principles and Standard Disclosures, Amsterdam: GRI.

Hart, S. L., Milstein, M. B. (2003) "Creating sustainable value", Academy of Management Executive, Vol. 17, No. 2, pp. 56-69, doi: 10.5465/ame.2003. 10025194.

Herzig, H., Schaltegger, S. (2006) "Corporate Sustainability Reporting: An Overview". In Schaltegger, S., Bennett, M., Burritt, R., ed., Sustainability Accounting and Reporting. Dordrecht: Springer, doi: 10.1007/978-1-40204974-3_13.

International Integrated Reporting Council (2012) Towards integrated reporting Communicating value in the $21^{\text {st }}$ century, London: IIRC.

International Integrated Reporting Council (2013) International Integrated Reporting Framework, London: IIRC.

Kapoor, S., Sandhu, H. S. (2010) "Does it Pay to be Socially Responsible? An Empirical Examination of Impact of Corporate Social Responsiblity on Financial Performance" Global Business Review, Vol. 11, No. 2, pp. 185-208, doi: 10.1177/097215091001100205.

KPMG (2015) Survey of Corporate Responsibility Reporting: Currents of Change, Netherlands: Haymarket Network Ltd, KPMG International.

Kuosmanen, T., Kuosmanen, N. (2009) "How not to measure sustainable value (and how one might)", Ecological Economics, Vol. 69, No. 2, pp. 235-243, doi: 10.1016/j.ecolecon.2009.08.008.

Lii, YS., Lee, M. (2012) "Doing Right Leads to Doing Well: When the Type of CSR and Reputation Interact to Affect Consumer Evaluations of the Firm", Journal of Business Ethics, Vol. 105, No. 1, pp. 69-81, doi: 10.1007/s10551011-0948-0.

Lyrstedt, F. (2005) Measuring Eco-efficiency by a LCC/LCA Ratio: An Evaluation of its Applicability, Master of Science Thesis, Göteborg, Sweden: CPM - Centre for Environmental Assessment of Product and Material Systems.

Maistriau, A. E., Bonardi, J. P. (2014) "How Much Does Negative Public Exposure on Environmental Issues Increase Environmental Performance?", Academy Of Management Proceedings [Internet], Vol. 2014, No. 1, pp. 1-40. Available at: $<$ http://webcache.googleusercontent.com/search?q=cache:fKqgto0T_AIJ:www. kellogg.northwestern.edu/ /media/Files/Research/fordcenter/sbe-2014/ Maistriau-Bonardi_april2014.ashx $+\& \mathrm{~cd}=1 \& \mathrm{hl}=\mathrm{hr} \& \mathrm{ct}=\mathrm{clnk} \& \mathrm{gl}=\mathrm{hr}>$ [Accessed: December 1, 2017].

Miljenović, D. (2016) "Smjernice i standardi nefinancijskog izvještavanja", Računovodstvo, revizija i financije, Vol. 26, No. 5, pp. 42-48.

Olsthoorn, X. et al. (2001) "Environmental indicators for business: a review of the literature and standardisation methods", Journal of Cleaner Production, Vol. 9, No. 5, pp. 453-463, doi: 10.1016/s0959-6526(01)00005-1. 
Orlitzky, M., Schmidt, F. L., Rynes, S. L. (2003) "Corporate Social and Financial Performance: A Meta Analysis”, Organization Studies, Vol. 24, No. 3, pp. $403-$ 441, doi: 10.1177/0170840603024003910.

Peloza, J., Papania, L. (2008) “The missing link between corporate social responsibility and financial performance: Stakeholder salience and identification", Corporate Reputation Review, Vol. 11, No. 2, pp. 169-181, doi: 10.1057/crr.2008.13.

Peloza, J. (2009) "The Challenge of Measuring Financial Impacts From Investments in Corporate Social Performance. Journal of Management", Vol. 35, No. 6, pp. 1518-1541, doi: 10.1177/0149206309335188.

Petrini, M., Pozzebon, M. (2009) "Managing sustainability with the support of business intelligence: Integrating socio-environmental indicators and organisational context", Journal of Strategic Information Systems, Vol. 18, No. 4, pp. 178-191, doi: 10.1016/j.jsis.2009.06.001.

Salaiz, A. (2015) "Is Corporate Social Performance a Balancing Act? The impact of CSR and CSiR on Firm Reputation". In Academy Of Management Proceedings - AOM Annual Meeting, January, New York: AOM, p. 14682, doi: 10.5465/ ambpp.2015.14682abstract.

Tideman, S. G. (2005) Mind Over Matter - Towards a New Paradigm for Leadership in Business and Economics, Amsterdam: Van Ede Foundation.

Veleva, V., Ellenbecker, M. (2001) "Indicators of sustainable production: framework and methodoloy", Journal of Cleaner Production, Vol. 9, No. 6, pp. 519-549, doi: 10.1016/s0959-6526(01)00010-5.

Vollmann T. (1996) The transformation imperative: achieving market dominance through radical change, Boston, MA: Harvard Business School Press. 


\title{
Testiranje održive dodane vrijednosti kao integralne mjere održivog poslovanja
}

\author{
Dejan Miljenovic ${ }^{1}$
}

\begin{abstract}
Sažetak
Implementacija poslovnih modela zasnovanih na društvenoj odgovornosti poduzeća (DOP) i trostrukom rezultatu poduzeća (eng. Triple Bottom Line - TBL) zastupa $i$ novi analitički pristup namijenjen cjelovitoj procjeni ekonomske vrijednosti. Budući da su DOP i TBL strateški orijentirani na ciljeve održivog razvoja i eko-efikasnosti u poslovanju, nova promatrana ekonomska vrijednost naziva se održivom dodanom vrijednosti (eng. Sustainable Value Added - SVA). Dosadašnja istraživanja $i$ konstruktivne kritike SVA modela nisu prikladno testirani primjenom odgovarajućih ekonometrijskih modela. $U$ ovom radu autor predstavlja primjenjiv empirijski model testiranja SVA kao mjeru koja integrira aspekte TBL-a: 1) financijski, 2) okolišni i 3) društveni. Cilj ovog istraživanja je potvrditi SVA kao integralnu mjeru koja se isključivo može koristiti za kvantitativnu procjenu dugoročnih učinaka koje poduzeće ostvaruje u smislu doprinosa održivom razvoju. Autor pritom zastupa i tezu da je procjena SVA moguća samo kada značajan broj poduzeća iz različitih industrijskih sektora redovito objavljuje godišnja izvješća o DOP-u. Time se osigurava prezentacija potpunih $i$ standardiziranih podataka trostrukog rezultata potrebnih za analizu SVA. U ovom radu SVA se uspoređuje s tradicionalnom ekonomskom mjerom dodane vrijednosti (Value Added - VA), ali u smislu doprinosa održivosti. Rezultati empirijskog testiranja ukazuju na značajne razlike između mjera VA i SVA, osobito u smislu integriranja financijskih, okolišnih i društvenih učinaka poslovanja. Testiranjem je SVA signifikantno potvrđena kao djelotvorna, a time i prikladna integralna mjera poslovnih doprinosa u domeni održivog razvoja. U tom smislu, dodatni cilj je istražiti eko-efikasnost specifične vrijednosti kao uvjeta održivosti, mjerenog upotrebom SVA-a.
\end{abstract}

Ključne riječi: društvena odgovornost poduzeća, održiva dodana vrijednost, trostruki rezultat, izvještavanje, poduzeće, održivost

JEL klasifikacija: O31, Q32, Q57

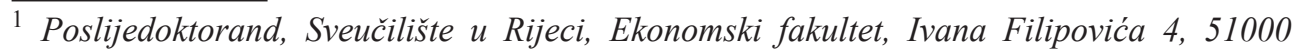
Rijeka, Hrvatska. Znanstveno područje: ekonomika poduzetništva. Tel.: +38551355136. E-mail: dejan.miljenovic@efri.hr. Osobna web stranica: https://www.efri.uniri.hr/hr/ dejan_miljenovic/195/72. 